\title{
Output of Luteinizing Hormone in the Urine of Normal Children and Those with Advanced Sexual Development
}

\author{
J. M. H. BUCKLER and BARBARA E. CLAYTON \\ From the Department of Chemical Pathology, The Hospital for Sick Children, and Institute of Child Health, \\ Great Ormond Street, London
}

\begin{abstract}
Buckler, J. M. H., and Clayton, B. E. (1970). Archives of Disease in Childhood, 45, 478. Output of luteinizing hormone in the urine of normal children and those with advanced sexual development. Estimations by radioimmunoassay of the 24-hour excretion of LH in normal children (152 boys and 104 girls) have shown high values in the first six months of life in boys, and possibly girls, and then low levels until the age of about 6 years. There is then a gradual rise in LH excretion in both sexes which continues for the 3-4 years which precede the onset of puberty, at which age a more marked increase occurs. 13 cases of true precocious puberty were all found to be associated with increased urinary excretion of $\mathrm{LH}$, a feature that was seldom shown with other forms of advanced sexual development. Measurement of urinary $\mathrm{LH}$ excretion provides a useful tool in the differentiation of such conditions.
\end{abstract}

Much still remains to be known about the mechanisms for the initiation and regulation of puberty. Until recently there had been few studies of gonadotrophin levels in childhood and adolescence, and these few were by bioassay methods not sufficiently sensitive to detect minor changes. Since the introduction of the radioimmunoassay, more sensitive and accurate determinations have become feasible, but most studies in children refer to gonadotrophin levels in serum. The present study reports levels of luteinizing hormone (LH) in 24-hour collections of urine from normal children of all ages, and from children with precocious puberty. These results throw some light on one of the probable endocrine activities that precedes the more obvious changes at puberty.

\section{Subjects and Methods}

Controls. The study was conducted on 152 boys (aged from 3 days to $12 \frac{1}{2}$ years) and 104 girls (aged 3 months to 14 years) who were considered as normals. 122 of these boys and 78 of the girls were under the age of 9 years, and had no evidence of onset of puberty. The remaining children were assessed for staging of pubertal development by the method of Tanner (1962), but there were insufficient numbers for satisfactory analysis. These children were mostly hospital in-

Received 3 December 1969. patients undergoing treatment for various conditions, but were not acutely ill or suffering from endocrine disorders. Many were undergoing minor surgical procedures, such as operations on the ears, nose, or throat.

Children with advanced sexual development. 5 boys and 8 girls with features of true precocious puberty (i.e. with evidence of advanced gonadal development) were included in this study, and the details of these children are included in Table I. In addition, there were 2 boys and 9 girls with various features of advanced sexual development but lacking the full picture of true precocious puberty, and one true hermaphrodite (Table II). Many of these children were undergoing investigations as hospital in-patients but a few collected urine as out-patients. Cases of precocious sexual development known to be of adrenal origin have been excluded from the study.

Estimation of $\mathrm{LH}$ in urine. 24-hour collections of urine were preserved with merthiolate or chloroform and stored at $-20^{\circ} \mathrm{C}$. before assay of $\mathrm{LH}$ content. Repeat collections on different days were obtained from several children. The urine samples were processed by the ethanol precipitation method described by Raiti and Blizzard (1968). The dried precipitates were redissolved in buffer of such a volume as effectively to concentrate the urine fourfold. The $\mathrm{LH}$ in the urine was estimated by a double antibody radioimmunoassay (Buckler and Clayton, 1970). The antiserum chosen for use in this assay was raised to human chorionic 


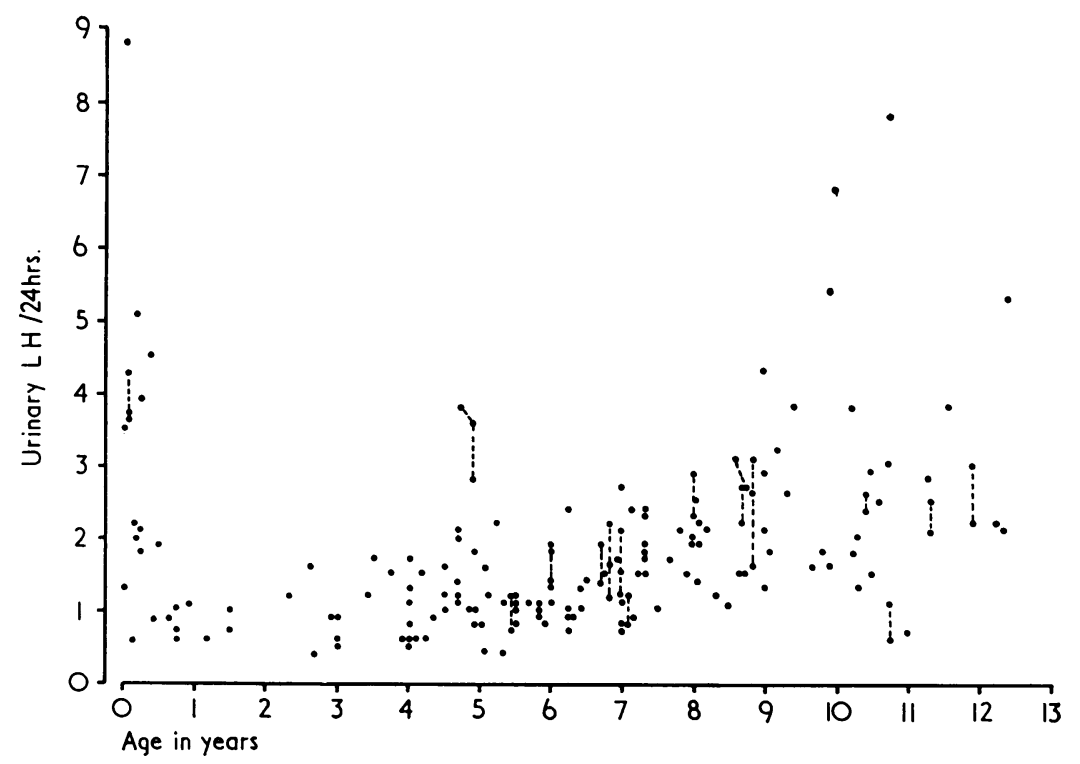

FIG. 1.-Amounts of LH (in terms of 2nd IRP) in 24-hour collections of urine from normal boys. Interrupted lines join values for repeat estimations on the same children. The exceptional result in one of the 5-year-old boys has been excluded from Table III.

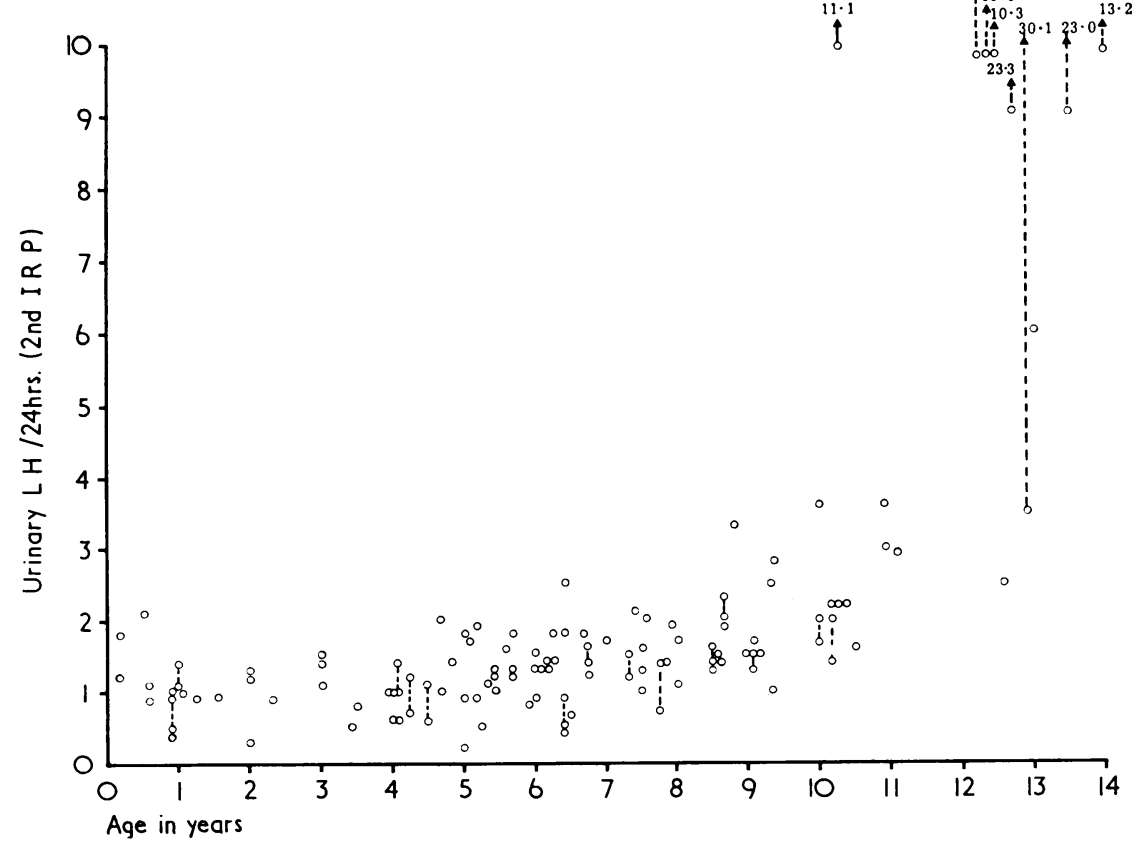

FIG. 2.-Amounts of LH (in terms of 2nd IRP) in 24-hour collections of urine from normal girls. Interrupted lines join values for repeat estimations on the same children. 
Features and Findings in: $\mathrm{Ca}$

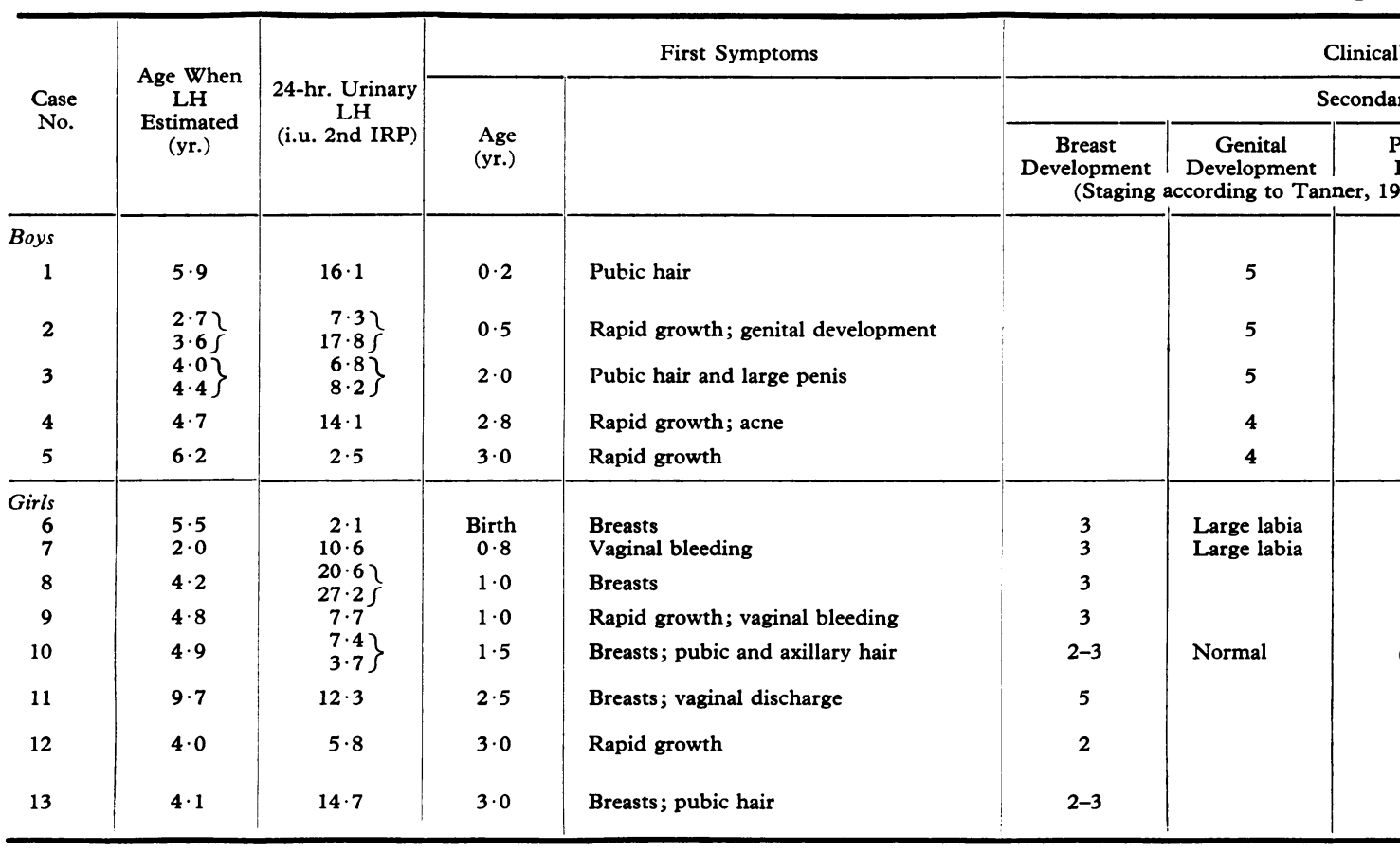

$\star N S=$ not studied.

gonadotrophin (HCG) in a guinea-pig and shown to cross-react only slightly with follicle stimulating hormone (FSH) and thyrotrophic hormone (TSH). The antiserum had been treated with extracts from the urine of young children to remove non-specific cross reactants.

Results given are the mean of duplicate assays at 3 dilutions (undiluted and concentrated twofold and fourfold) and are reported in terms of the Second International Reference Preparation of Human Menopausal Gonadotrophin (2nd IRP) (kindly supplied by Dr. D. R. Bangham, National Institute for Medical Research, London). Estimations on repeated urine collections from the same children on different days (often before and after minor surgery) have usually shown only minor variations in LH content.

Sixteen recovery experiments have been included in the course of these studies and the values for recovery of added standard hormone (2nd IRP) averaged 103\%, with a standard deviation of $10 \cdot 3 \%$.

\section{Results}

LH content of 24-hour collections of urine from normal children. The 24-hour urinary LH output for the normal boys is shown in the scatter diagram (Fig. 1) and for normal girls in Fig. 2. The mean values for the various age-groups before the onset of puberty are shown for boys in Table III and for girls in Table IV.

After the first 6 months of life, urinary LH output in both sexes remains low until about 6 years of age, when levels rise slowly but steadily. This increased LH output is shown to be significant statistically, particularly in boys. As the time of puberty approaches, and throughout puberty, these $\mathrm{LH}$ levels rise more steeply towards adult values, and become much more scattered.

During the first 6 months of life, LH levels in 24-hour urine collections of boys are higher than throughout the rest of prepubertal childhood. There are insufficient estimations to draw the same conclusion about girls.

LH levels in 24-hour urine collections from children with abnormal sexual development. The 24-hour urinary $\mathrm{LH}$ values obtained in children with true precocious puberty together with details of their clinical features and histories are shown in Table I. All of these 13 cases have levels in excess (usually considerable) of the normal range for the appropriate age (as assessed by the mean control values reported plus 1 standard deviation).

The results of the other 12 children with abnormal 


\begin{tabular}{|c|c|c|c|c|c|c|}
\hline \multicolumn{3}{|l|}{ Time of LH Estimation } & \multirow{3}{*}{$\begin{array}{c}\text { Bone } \\
\text { Age } \\
\text { (yr.) }\end{array}$} & \multirow{3}{*}{$\begin{array}{c}\text { Chrono- } \\
\text { logical } \\
\text { Age } \\
\text { (yr.) }\end{array}$} & \multirow{3}{*}{$\begin{array}{l}\text { Oestrogen } \\
\text { Effect }\end{array}$} & \multirow{3}{*}{ Pathological Cause } \\
\hline aracteristics & & iles & & & & \\
\hline \multirow[t]{6}{*}{ Vaginal Bleeding } & Height & Weight & & & & \\
\hline & & & $\left.\begin{array}{c}6-8 \\
14-15\end{array}\right\}$ & $\begin{array}{l}2 \cdot 2\} \\
5 \cdot 9\}\end{array}$ & & Idiopathic \\
\hline & 97 & $>97$ & $\left.\begin{array}{r}3 \\
10\end{array}\right\}$ & $\left.\begin{array}{l}2 \cdot 6 \\
4 \cdot 0\end{array}\right\}$ & & Suprasellar tumour; ( ?hamartoma) \\
\hline & $>97$ & $>97$ & $12 \cdot 0$ & $4 \cdot 0$ & & Idiopathic \\
\hline & $>97$ & $>97$ & $\begin{array}{l}13 \cdot 5\} \\
16.5\end{array}$ & $\left.\begin{array}{r}4 \cdot 1 \\
6.0\end{array}\right\}$ & & Idiopathic \\
\hline & $>97$ & $>97$ & 14 & $6 \cdot 2$ & & Idiopathic \\
\hline $\begin{array}{l}\text { Every } 6 \mathrm{mth} \text {. since } 1.7 \mathrm{yr} \text {. } \\
\text { Every } 2 \mathrm{mth} \text {. since } 0.8 \mathrm{yr} \text {. }\end{array}$ & $\begin{array}{c}90-97 \\
>97\end{array}$ & $\begin{array}{c}90 \\
>97\end{array}$ & $\begin{array}{r}9 \\
>4\end{array}$ & $\begin{array}{l}5 \cdot 4 \\
2 \cdot 0\end{array}$ & $\begin{array}{c}\text { *NS } \\
+\end{array}$ & $\begin{array}{l}\text { Albright's syndrome } \\
\text { Hypothalamic tumour; ?hamartoma }\end{array}$ \\
\hline 一 & $>97$ & $>97$ & 10 & $4 \cdot 2$ & + & Chronic subdural haematoma \\
\hline 3 episodes at $1 \cdot 2,2$, and $3 \cdot 5 \mathrm{yr}$. & $>97$ & $>97$ & $12 \cdot 5$ & $4 \cdot 7$ & $\star N S$ & ?Ovarian cyst (ruptured at $3 \frac{1}{2}$ yr.) ?idiopathic \\
\hline - & $>97$ & $90-97$ & 8 & $4 \cdot 9$ & + & Idiopathic \\
\hline Monthly since $7 \mathrm{yr}$. & $75-90$ & 75 & $\left.{ }_{14-15}^{6}\right\}$ & $\left.\begin{array}{l}3 \cdot 5 \\
9 \cdot 8\end{array}\right\}$ & $\star \mathbf{N S}$ & Third ventricular tumour \\
\hline Monthly since $3 \cdot 7 \mathrm{yr}$. & $>97$ & $>97$ & $\begin{array}{r}8\} \\
10\}\end{array}$ & $\left.\begin{array}{l}4 \cdot 0 \\
4 \cdot 9\end{array}\right\}$ & + & Suprasellar mass ( ?hypothalamic tumour) \\
\hline - & $>97$ & $>97$ & $7-8$ & $4 \cdot 1$ & + & Idiopathic \\
\hline
\end{tabular}

sexual development are similarly shown in Table II. In most of these, the $\mathrm{LH}$ levels are within the normal range, and the nature of the abnormality is apparent, but in 2, a diagnosis of idiopathic precocious puberty could not be excluded. The 2 eldest children of this group did have a high $\mathrm{LH}$ output, and were probably entering normal adolescence at a rather early stage.

\section{Discussion}

By bioassay methods, detectable low levels of gonadotrophins have been found in pooled samples of urine collected from children over several days (Fitschen, 1963; Fitschen and Clayton, 1965), though Kulin et al. (1967) found considerable variation from day to day. There are only a few reports of radioimmunoassays being applied to the estimation of LH levels in children's urine (Bagshawe, Wilde, and Orr, 1966; Kulin, Rifkind, and Ross, 1968). Estimations on untreated urine samples give values that are much higher than those found with processed urines or bioassays (Kulin et al., 1968; Stevens, 1969). The present study reports the results with urine samples treated by ethanol precipitation.
Though a number of workers have reported $\mathrm{LH}$ estimates in sera of children (e.g. Kenny et al., 1968, 1969; Root et al., 1968; Schalch et al., 1968b; Johanson et al., 1969), the variation in results is considerable, and many reports indicate no significant differences between the values of adults and children. We have found that with the low levels occurring in children, we are not satisfied with any of the methods at present available for estimating these values in sera. Serum estimations reflect only random samples and are not necessarily an indication of the mean values over 24 hours. In addition, there is at present no suitable standard on which to base serum LH estimations, and values given are reported in terms of pituitary reference materials or 2nd IRP, neither of which are likely to be equivalent immunologically to the form of $\mathrm{LH}$ that occurs in serum.

That LH output increases at the time of puberty is well recognized, and bioassay studies had suggested that the rise in $\mathrm{LH}$ at that time was more marked than that of FSH (Brown, 1958; Rifkind, Kulin, and Ross, 1967). The report of Johanson et al. (1969) on serum LH levels in children suggested that this rise could be correlated with the 
Features and Findings in Casest wi

\begin{tabular}{|c|c|c|c|c|c|c|}
\hline \multirow{3}{*}{$\begin{array}{l}\text { Case } \\
\text { No. }\end{array}$} & \multirow{3}{*}{$\begin{array}{l}\text { Age When } \\
\text { LH } \\
\text { Estimated } \\
\text { yr. }\end{array}$} & \multirow{3}{*}{$\begin{array}{l}\text { 24-hr. Urinary } \\
\text { LH } \\
\text { (i.u. 2nd IRP) }\end{array}$} & \multicolumn{2}{|r|}{ First Symptoms } & \multirow{2}{*}{\multicolumn{2}{|c|}{ Clinical }} \\
\hline & & & \multirow[b]{2}{*}{$\begin{array}{c}\text { Age } \\
\text { (yr.) }\end{array}$} & & & \\
\hline & & & & & $\begin{array}{c}\text { Breast } \\
\text { Development } \\
\text { (Staging ac }\end{array}$ & $\begin{array}{c}\text { Genital } \\
\text { Development } \\
\text { cording to Tan }\end{array}$ \\
\hline \multirow{2}{*}{$\begin{array}{r}\text { Boys } \\
1\end{array}$} & & & & & & \\
\hline & $9 \cdot 3$ & $3 \cdot 3$ & Birth & $\begin{array}{l}\text { Slow weight gain; lipodystrophy } \\
\text { Rapid growth; behaviour disorder }\end{array}$ & & $\begin{array}{l}\text { Large penis } \\
\text { and } \\
\text { scrotum; } \\
\text { testes } \\
\text { slightly } \\
\text { enlarged } \\
\text { Large penis }\end{array}$ \\
\hline $\begin{array}{r}\text { Girls } \\
\mathbf{3}\end{array}$ & & & & & & \\
\hline 3 & $1 \cdot 3$ & $0 \cdot 4$ & Birth & $\begin{array}{l}\text { Slow weight gain; enlarged labia and } \\
\text { clitoris }\end{array}$ & 2 & $\begin{array}{c}\text { Moderate } \\
\text { enlarge- } \\
\text { ment of } \\
\text { labia and } \\
\text { clitoris }\end{array}$ \\
\hline 4 & 0.9 & $0 \cdot 4-1 \cdot 0$ & 0.5 & Pubic hair & 2 & $\begin{array}{l}\text { Slight } \\
\text { clitoral } \\
\text { enlarge- } \\
\text { ment }\end{array}$ \\
\hline 5 & 0.9 & $\left.\begin{array}{l}1 \cdot 0 \\
2 \cdot 1\end{array}\right\}$ & $0 \cdot 6$ & Pubic hair; breasts & 2 & \\
\hline $\begin{array}{l}6 \\
7 \\
8 \\
9\end{array}$ & $\begin{array}{l}2 \cdot 8 \\
7.9 \\
6 \cdot 5 \\
6 \cdot 5\end{array}$ & $\begin{array}{l}1 \cdot 1 \\
2 \cdot 1 \\
0.5 \\
1 \cdot 2\end{array}$ & $\begin{array}{l}2 \cdot 0 \\
4 \cdot 0 \\
6 \cdot 0 \\
6 \cdot 0\end{array}$ & $\begin{array}{l}\text { Breasts } \\
\text { Vaginal bleeding } \\
\text { Vaginal discharge; body odour } \\
\text { Pubic hair }\end{array}$ & $\begin{array}{l}2 \\
2 \\
1 \\
1\end{array}$ & $\begin{array}{l}\text { Normal } \\
\text { Normal } \\
\text { Normal }\end{array}$ \\
\hline 10 & $9 \cdot 4$ & $4 \cdot 6$ & $7 \cdot 0$ & Pubic hair & 1 & $\begin{array}{l}\text { Slight } \\
\text { clitoral } \\
\text { and labial } \\
\text { enlarge- } \\
\text { ment }\end{array}$ \\
\hline 11 & $9 \cdot 0$ & $1 \cdot 7$ & $8 \cdot 6$ & Pubic hair & 1 & \\
\hline \multicolumn{2}{|c|}{ Hermaphrodite } & & & & & \\
\hline 12 & 0.5 & 0.4 & Birth & Ambiguous genitalia & 1 & $\begin{array}{l}\text { Enlarged } \\
\text { clitoris } \\
\text { and labia; } \\
\text { single } \\
\text { urogenital } \\
\text { opening }\end{array}$ \\
\hline
\end{tabular}

.

으

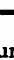


me Abnormal Sexual Characteristics

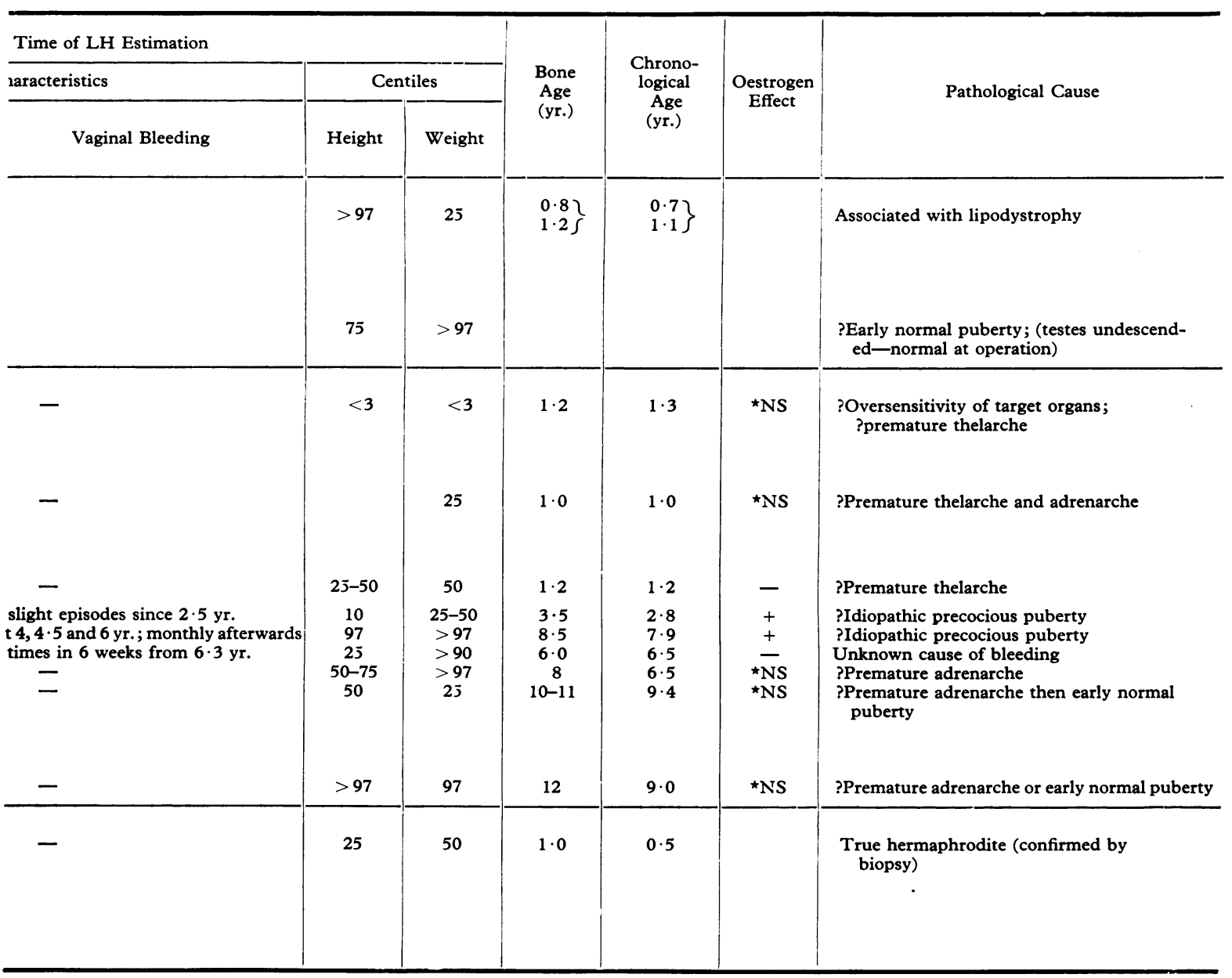

children (Schonfeld, 1943). However, these cells disappear after 4 to 6 weeks and have been attributed to maternal pituitary or chorionic gonadotrophin stimulation.

Reports based on bioassay studies of cases of precocious puberty have given varied results, as have also those depending on radioimmunoassay of serum LH. Schalch and Bryson (1967) reported no increase in serum $\mathrm{LH}$ in 3 girls with true precocious puberty, and Root et al. (1968) found high serum LH levels in only 2 out of 22 children with sexual precocity (of various kinds), and these 2 were due to intracranial lesions. Yet Kenny et al. (1969) showed raised plasma LH and FSH levels in
20 girls with idiopathic precocious puberty (but not in 2 when the cause was a granulosa cell tumour of the ovary). These workers found slight increases in $\mathrm{LH}$ and FSH also in 26 cases of premature thelarche, but somewhat lower than normal levels in 5 girls with premature adrenarche.

The present report suggests that cases of true precocious puberty (involving increased activity of gonads, adrenal and pituitary), whether these are neurogenic in origin or idiopathic, are usually associated with raised levels of urinary LH. When the full picture including gonadal activity is not found, there is usually no increase in LH output. Such children show features of premature sexual 
TABLE III

LH Levels in Urine of Normal Prepubertal Boys

\begin{tabular}{|c|c|c|c|}
\hline Age (yr.) & $\begin{array}{l}\text { No. } \\
\text { Tested }\end{array}$ & $\begin{array}{l}\text { Urinary LH i.u. } \\
\text { 2nd IRP/24 hr. } \\
\quad \pm 1 \text { SD }\end{array}$ & $\begin{array}{l}\text { Statistical Significance } \\
\text { of Differences }\end{array}$ \\
\hline $0-0.5$ & 15 & $3 \cdot 1 \pm 2 \cdot 1$ & $\begin{array}{l}\text { Compared with } 0.5-6 \\
\text { yr. } p<0.001\end{array}$ \\
\hline $\begin{array}{l}0 \cdot 5-1 \\
1-2 \\
2-3 \\
3-4 \\
4-5 \\
5-6\end{array}$ & $\begin{array}{r}5 \\
3 \\
3 \\
9 \\
22 \\
16\end{array}$ & $\begin{array}{l}0.9 \pm 0.21 \\
0.8 \pm 0.21 \\
1.07 \pm 0.61 \\
1.00 \pm 0.42 \\
1.13 \pm 0.41 \\
1.03 \pm 0.43\end{array}$ & \\
\hline $0.5-6$ & 58 & $1.04 \pm 0.42\}$ & \\
\hline $6-7$ & 15 & $1.37 \pm 0.45\}$ & p $<00.02$ \\
\hline $7-8$ & 19 & $1.58 \pm 0.59\}\}$ & p $<0.3$ \\
\hline $8-9$ & 15 & $2.05 \pm 0.61\}$ & $p<0.03$ \\
\hline $7-9$ & 34 & $1 \cdot 80 \pm 0.59$ & $\begin{array}{l}\text { Compared with } 6-7 \mathrm{yr} \text {. } \\
\quad \mathrm{p}<0.01\end{array}$ \\
\hline
\end{tabular}

development but lack evidence of spermatogenesis or oestrogen excess (as reflected by cornification of the vaginal mucosa), and often, as in premature thelarche, have no advancement of bone age or stature. These findings indicate the value of radioimmunoassay of $\mathrm{LH}$ levels in urine as a diagnostic aid in differentiating cases of precocious puberty and those with other advanced sexual characteristics.

We wish to thank members of the Medical Staff of The Hospital for Sick Children, Great Ormond Street, for allowing us to study these children, and to the nursing staff for co-operation in obtaining the urine collections.

We are grateful for financial support from the Smith, Kline, and French Foundation and the Joint Research Board of The Hospital for Sick Children and Institute of Child Health, London.

\section{REFERENCES}

Bagshawe, K. D., Wilde, C. E., and Orr, A. H. (1966), Radioimmunoassay for human chorionic gonadotrophin and luteinising hormone. Lancet, 1, 1118.

Brown, P. S. (1958). Human urinary gonadotrophins. I. In relation to puberty. Fournal of Endocrinology, 17, 329.

Buckler, J. M. H., and Clayton, B. E. (1970). Studies on the specificity of the radioimmunoassay of luteinising hormone. Acta Endocrinologica, 63, 545.

Fitschen, W. (1963). Studies on the assay of pituitary gonadotrophins and growth hormone with particular reference to children. Ph.D. Thesis, University of London.

- , and Clayton, B. E. (1965). Urinary excretion of gonadotrophins with particular reference to children. Archives of Disease in Childhood, 40, 16.

Johanson, A. J., Guyda, H., Light, C., Migeon, C. J., and Blizzard, R. M. (1969). Serum luteinizing hormone by radioimmunoassay in normal children. Fournal of Pediatrics, 74, 416.

Kaplan, S. L., Grumbach, M. M., and Shepard, T. H. (1969). Gonadotrophins in serum and pituitary of human fetuses and infants. (Abstr.) Pediatric Research, 3, 512.

Kenny, F. M., Midgley, A. R., Jr., Jaffe, R. B., Garces, L. Y., and Vazquez, A. (1968). Radioimmunoassay of luteinizing hormone
TABLE IV

LH Levels in Urine of Normal Prepubertal Girls

\begin{tabular}{|c|c|c|c|}
\hline Age (yr.) & $\begin{array}{l}\text { No. } \\
\text { Tested }\end{array}$ & $\begin{array}{l}\text { Urinary LH i.u. } \\
\text { 2nd IRP/24 hr. } \\
\quad \pm 1 \mathrm{SD}\end{array}$ & $\begin{array}{c}\text { Statistical Significance } \\
\text { of Differences }\end{array}$ \\
\hline $\begin{array}{l}0-0.5 \\
0.5-1 \\
1-2 \\
2-3 \\
3-4 \\
4-5 \\
5-6\end{array}$ & $\begin{array}{r}3 \\
2 \\
4 \\
4 \\
4 \\
12 \\
15\end{array}$ & $\begin{array}{l}1.7 \pm 0.46 \\
1.0 \pm 0.14 \\
1.05 \pm 0.13 \\
0.9 \pm 0.45 \\
1.05 \pm 0.48 \\
1.12 \pm 0.42 \\
1.17 \pm 0.53\end{array}$ & \\
\hline $0 \cdot 5-6$ & 41 & $1 \cdot 10 \pm 0.43 ?$ & \\
\hline $6-7$ & 16 & $1.36 \pm 0.51 \mathrm{~J}$ & $p<0.4$ \\
\hline $\begin{array}{l}7-8 \\
8-9\end{array}$ & $\begin{array}{r}10 \\
8\end{array}$ & $\left.\begin{array}{l}1.52 \pm 0.35 \\
1.85 \pm 0.69\end{array}\right\}$ & $\mathrm{p}<0.3$ \\
\hline $6-8$ & 26 & $1.42 \pm 0.45$ & $\begin{array}{l}\text { Compared with } 0.5-6 \\
\text { yr. p }<0.01\end{array}$ \\
\hline
\end{tabular}

(LH) and follicle-stimulating hormone (FSH) in normal children and various abnormal conditions. (Abstr.) fournal of Pediatrics, 72, 565.

, and Taylor, F. H. (1969). Radioimmunoassayable serum LH and FSH in girls with sexua precocity, premature thelarche and adrenarche. fournal of Clinical Endocrinology, 29, 1272.

Kulin, H. E., Rifkind, A. B., and Ross, G. T. (1968). Human luteinizing hormone ( $\mathrm{LH}$ ) activity in processed and unprocessed urine measured by radioimmunosasay and bioassay. Fournal of Clinical Endocrinology, 28, 543.

- and Odell, W. D. (1967). Total gonadotropi activity in the urine of prepubertal children. Fournal of Clinical Endocrinology, 27, 1123.

Raiii, S., and Blizzard, R. M. (1968). Measurement of immunologically reactive follicle stimulating hormone in human urine by radioimmunoassay. Fournal of Clinical Endocrinology, 28, 1719.

Rifkind, A. B., Kulin, H. E., and Ross, G. T. (1967). Folliclestimulating hormone (FSH) and luteinizing hormone (LH) in the urine of prepubertal children. Fournal of Clinical Investigation, 46, 1925.

Root, A. W., Moshang, T., Jr., Bongiovanni, A. M., and Eberlein W. R. (1968). The relationship of plasma luteinizing hormone (LH) concentration to gonadal function. Pediatric Research, 2, 309.

Schalch, D. S., and Bryson, M. F. (1967). Plasma luteinizing hormone levels in normal children and in normal subjects with pituitary and gonadal dysfunction: determination by radioimmunoassay. Pediatric Research, 1, 308.

- - and Lee, L. A. (1968a). Plasma FSH levels in normal children and in children with various pituitary or gonadal disorders. Pediatric Research, 2, 308.

-, Parlow, A. F., Boon, R. C., and Reichlin, S. (1968b). Measurement of human luteinizing hormone in plasma by radioimmunoassay. Fournal of Clinical Investigation, 47, 665.

Schonfeld, W. A. (1943). Primary and secondary sexual characteristics. American fournal of Diseases of Children, 65, 535.

Stevens, V. C. (1969). Comparison of FSH and LH patterns in plasma, urine and urinary extracts during the menstrual cycle. fournal of Clinical Endocrinology, 29, 904.

Tanner, J. M. (1962). Growth at Adolescence, 2nd ed. Blackwell, Oxford.

Correspondence to Dr. J. M. H. Buckler, Department of Paediatrics and Child Health, University of Leeds, 27 Blundell Street, Leeds LS1 3ET. 